\title{
Differential contribution of mismatch repair genes in the processing of DNA damage
}

\author{
Hernan Flores-Rozas \\ From The Science of Global Prostate Cancer Disparities in Black Men \\ Jacksonville, FL, USA. 27-29 August 2010
}

\section{Background}

Defects in mismatch repair (MMR) have been extensively documented as the underlying cause of several cancers, most notably colon cancer. Recently, MMR has been proposed to play a role in the transition to hormone independence in prostate cancer. It is proposed that MMR mediates the cytotoxic effects of DNA damaging agents by exerting a futile repair pathway which leads to double strand breaks (DSBs). Previous reports indicate that the sensitivity of cells defective in homologous recombination (HR) to the DNA alkylation is reduced by defects in MMR genes. The involvement of MMR in the pathogenesis of prostate cancer has only recently been investigated. Genetic differences in MMR genes between ethnic populations may account for different outcomes after therapy. These genetic backgrounds should be investigated further.

\section{Methods}

We have assessed the contribution of different MMR genes to the processing of alkylation damage in vivo. We have directly visualized recombination complexes formed upon DNA damage using fluorescent protein (FP) fusions in cells containing different MMR backgrounds.

\section{Results}

We find that msh6 mutants are more resistant than wild type cells to MNNG, and that an msh6 mutation rescues the sensitivity of rad52 strains more efficiently than an msh3 mutation. Analysis of RAD52-GFP tagged strains indicate that MNNG increases repair foci formation, and that the inactivation of the MHS2 and MSH6 genes but not MSH3 gene result in a reduction of the number

Correspondence: hernan.floresrozas@famu.edu

College of Pharmacy and Pharmaceutical Sciences, Florida A\&M University, Tallahassee, Florida, USA of foci formed. In addition, in the absence of HR, NHEJ could process the MNNG-induced DSBs as indicated by the formation of NHEJ-GFP tagged foci.

\section{Conclusions}

These data suggest that processing of the alkylation damage by MMR, mainly by MSH2-MSH6, is essential for damage processing and MMR status should be evaluated prior to therapy.

\section{Acknowledgements}

This work was supported by grant by the NIH Roadmap for Biomedical Research. Publication of this article was funded in part by the University of Florida Open-Access Publishing Fund.

Published: 11 August 2011

doi:10.1186/1750-9378-6-S1-A6

Cite this article as: Flores-Rozas: Differential contribution of mismatch repair genes in the processing of DNA damage. Infectious Agents and Cancer 2011 6(Suppl 1):A6.
Submit your next manuscript to BioMed Central and take full advantage of:

- Convenient online submission

- Thorough peer review

- No space constraints or color figure charges

- Immediate publication on acceptance

- Inclusion in PubMed, CAS, Scopus and Google Scholar

- Research which is freely available for redistribution

Submit your manuscript at www.biomedcentral.com/submit
C Biomed Central

\section{Biomed Central}

